University of Thi-Qar Journal Vol.14 No. r June 2019

Web Site: https://jutq.utq.edu.iq/index.php/main

Email: journal@jutq.utq.edu.iq

\title{
Assessment of the Performance of Stone Columns through the Seismic Wave Test: A Review \\ https://doi.org/10.32792/utq/utj/vol14/2/6
}

Nesreen Kurdy Al-Obaidy, Assad Ibrahim Al-Shueli, and

Hussein Shaia

Assistant Prof. / College of Engineering

University of Thi-Qar

Email: nissren-k@utq.edu.iq

Email: assadkhyoon@gmail

Email: hshaia@yahoo.com

\section{Abstract}

The geophysical testing is increasingly being employed in many geotechnical applications. It is preferred in monitoring the mechanical characteristics of the ground because of its economy, not time consuming and non-destructive nature. Seismic wave test is one of the geophysical methods which showed a potential in observing the general behaviour of the reinforced soil with stone columns. Findings in most cases showed that the seismic wave measurements was integrated with or compared to the conventional tests such as standard penetration test or cone penetration test. There was a noticeable success in identifying the enhancement achieved to the ground upon the strengthening with the column, specifically when the associated surveys can produce a clear image of the underground which interprets the variation in the soil properties not prior to the soil treatment only, but even after the treatment occurring. However, from practical point of view, there were still some restrictions with applying such a method, specifically relating to the extent of data gathered, technical concerns and the difficulty of measuring the waves or interpreting results with the presence of ground water. This paper summarizes the recent publication work concerning this technique 


\section{University of Thi-Qar Journal Vol.14 No. r June 2019}

Web Site: https://jutq.utq.edu.iq/index.php/main

\section{Email: journal@jutq.utq.edu.iq}

with a key focus on advantages and limitations within this type of ground improvement.

Keywords: Stone column, seismic wave test, soil improvement.

\section{تقييم أداء الأعمدة الحجرية خلال اختبار الموجة الزلزالية: مراجعة}

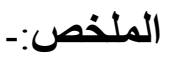

يتم استخدام الاختبارات الجيوفيزيائية بشكل متزايد وفي العديد من التطبيقات الجيوتقنتية. حيث

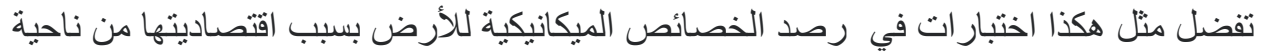

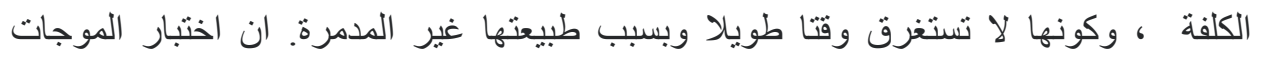

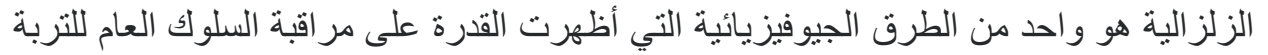

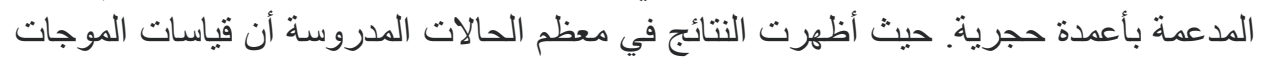

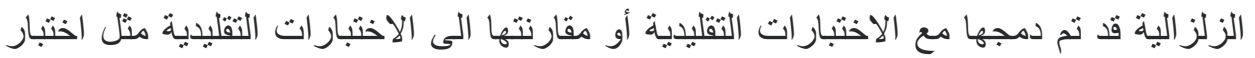

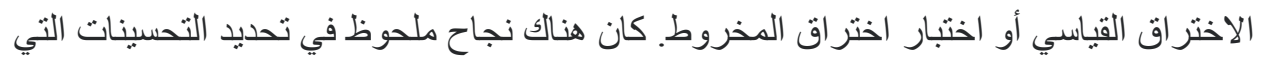

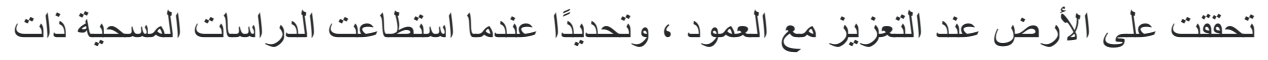

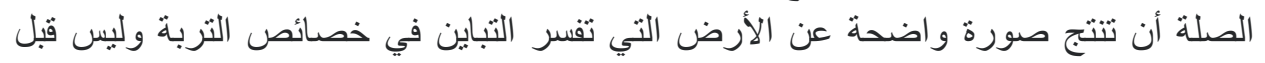

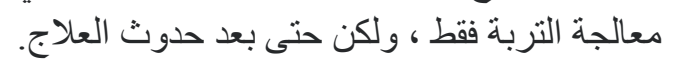

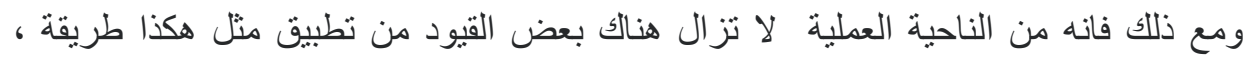

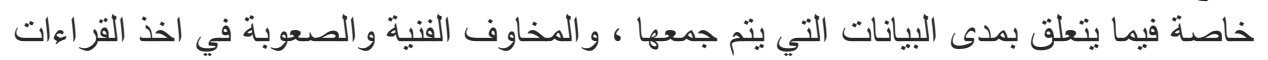

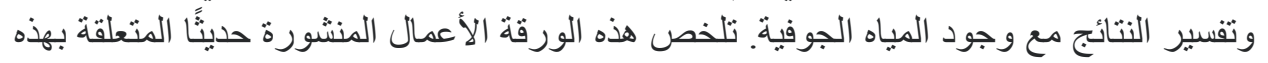
التقنية مع التركيز الرئيسي على المز ايا و القيود ضمن هذا التهو النوع من التحسينات الأرضية.

الكلمات المفتاحية: أعمدة حجرية ، اختبار الموجة الزلز الية ، تحسين تربة.

\section{Introduction}

Geophysical methods can assess the ground improvement in site irrespective to idealized condition assumptions that usually used in laboratory and numerical models as in most sites treated by ground improvement methods there are dealing with non-homogeneous and/or anisotropy soil [1]. Prior to ground treatment, geophysical systems can offer an effective, cost effective, non-invasive apparatus to monitor soil properties and resultant deformation but the improvement achieved post- 


\section{University of Thi-Qar Journal Vol.14 No. r June 2019}

Web Site: https://jutq.utq.edu.iq/index.php/main

Email: journal@jutq.utq.edu.iq

soil treatment is challenging to evaluate, as a result to the presence of the compressed masses of the column material into the ground, which could significantly affect the treated zone stiffness and its strength [2].

Recent studies referred to the prospect of estimating the shear moduli of the stone column from the velocity phase obtained from the seismic wave test [3-6]. Also, based on the seismic parameters, the liquefaction and lateral scattering in the soil commonly characterized with seismic hazards can be evaluated [7] and [8].

Moreover, the method shows a good performance for detecting longterm behaviour of Vibro Stone Column such as pore water pressure generation and dissipation after treatment is completed), whereas conventional methods could be used to study these effects in the short term only [3]. In contrast to the data obtained by standard penetration and cone test and penetration tests which based on small diameter of the bore hole and for a limited depth, the measurements from this method can cover a large area of the treated zone [9]. Elastic seismic waves is a geophysical technique that has been demonstrated to be a powerful with producing $2 \mathrm{D}$ or $3 \mathrm{D}$ image in many geotechnical practise. Nevertheless, there were some limits with using such a method, specifically relating to the extent of data recorded, the setup procedure and the accessibility of underground water [10].

This paper provides an overview in two directions, the first is relating to the basic concept of the technique with identification to the main types of the elastic seismic waves and the second is relating the background of the vibro stone column. Also, it presents recent examples of the application of elastic seismic waves in the soil improvement with vibro stone column.

\section{Elastic Seismic Waves}

The Elastic seismic waves are waves of the energy that travels through the earth substratum. There are four main types of elastic seismic waves which propagate at altered velocities that depend on density and elasticity of the medium. Figure 1 shows the main four 


\section{University of Thi-Qar Journal Vol.14 No. r June 2019}

Web Site: https://jutq.utq.edu.iq/index.php/main

\section{Email: journal@jutq.utq.edu.iq}

types of seismic waves. The four waves are: compression wave (P-wave), shear wave (S-wave), Rayleigh wave and Love wave [11]. P and S waves are called as body waves while Rayleigh and Love waves are known as surface waves.

Waves transmit the vibration's energy of soil particles in parallel or perpendicularly in specific directions according to their type. P-waves vibrate parallel to the direction of wave propagation whereas $\mathrm{S}$-waves vibrate in a perpendicular direction. The wave's amplitude is attenuated in fraction to the distance from a seismic source point. In general and with comparison to the body waves, surface waves attenuation are less and can propagated over prolonged distances [12].

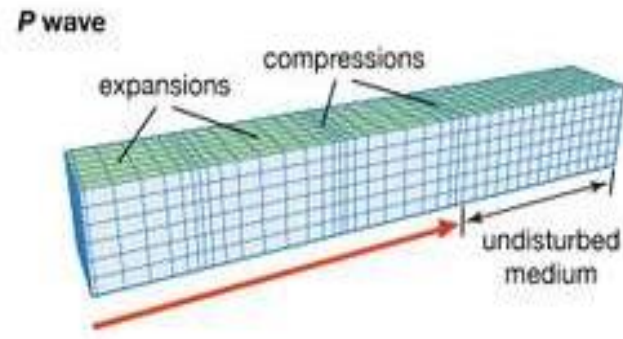

Love wave
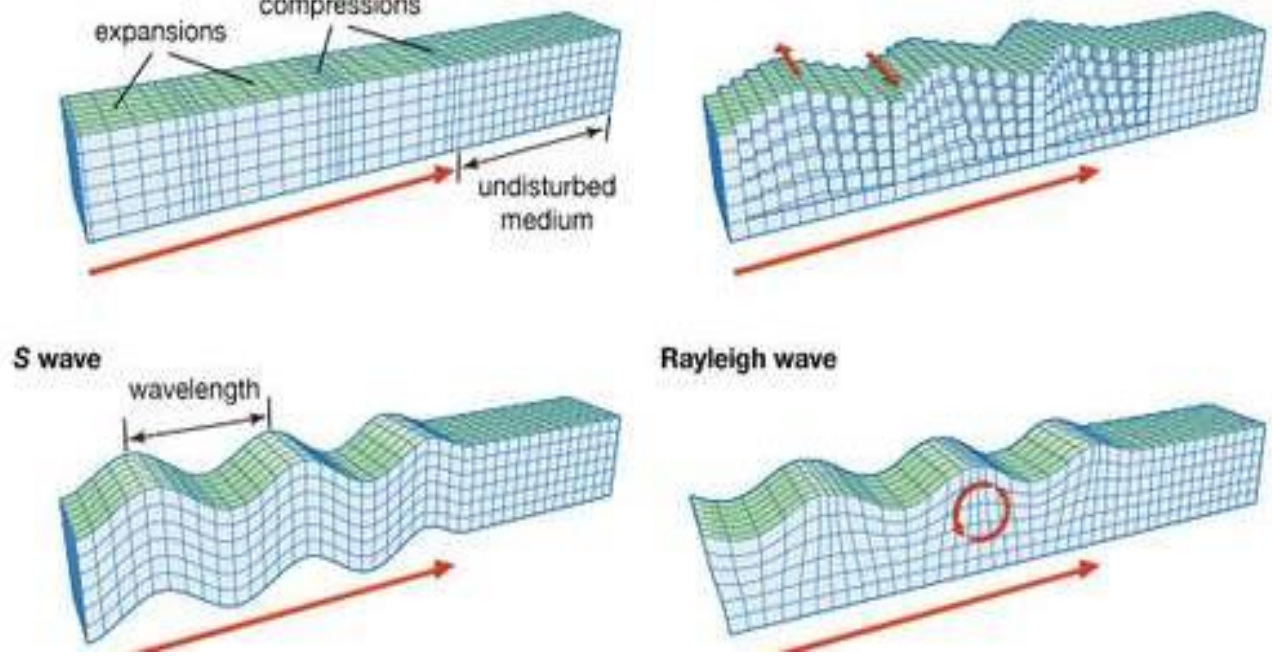

Rayleigh wave

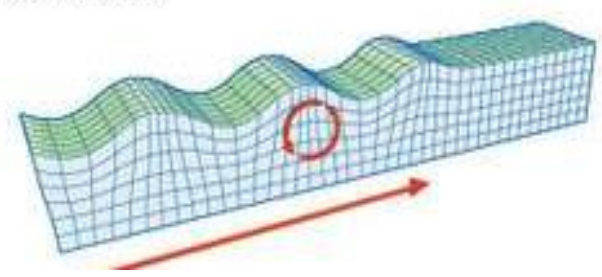

Figure 1: Main types of seismic wave [13]

The principle of determination the shear wave velocity from cone penetration rod for soil at site is measuring the interval between two 


\section{University of Thi-Qar Journal Vol.14 No. r June 2019}

Web Site: https://jutq.utq.edu.iq/index.php/main

Email: journal@jutq.utq.edu.iq

geophones after setting a seismic source at the ground surface [14] for more illustration see Fig. 2 .

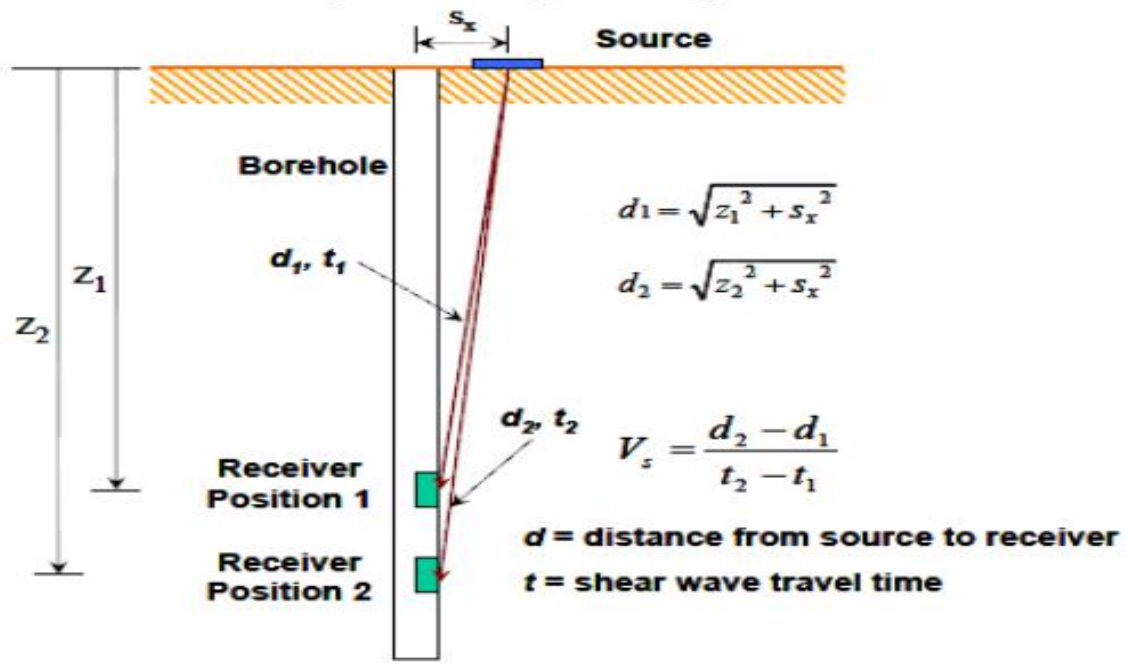

Figure 2: Sketch of determination the shear wave velocity by setting a vibrator source [14]

On other hand, the literature presented two main methods of gaining seismic wave measurements that can fundamentally be employed for ground improvements; borehole methods and surface methods [15] as shown in Fig. 3.

Borehole methods

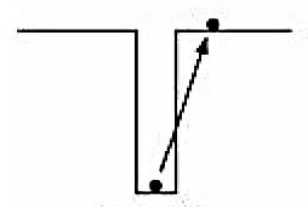

Up-hole

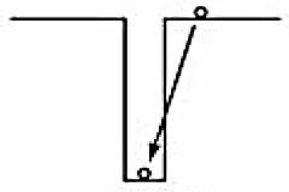

Down-hole

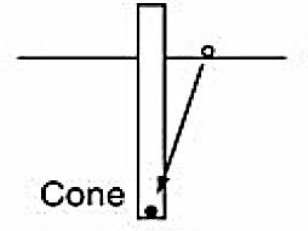

Seismic cone

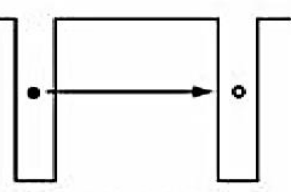

Cross-hole

\section{Surface methods}

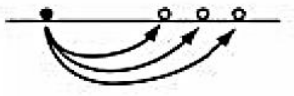

Refraction

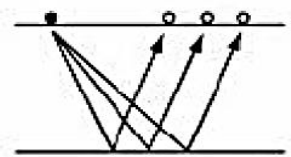

Reflection

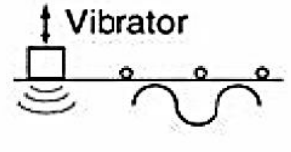

- Source

- Receiver

Surface wave 


\section{University of Thi-Qar Journal Vol.14 No. r June 2019}

Web Site: https://jutq.utq.edu.iq/index.php/main

\section{Email: journal@jutq.utq.edu.iq}

Figure 3: Sketch of borehole and surface methods to determine seismic wave for ground improvement survey in the field [15].

According to Menzies \& Matthews [15] and Clayton et al. [16], the stiffness profile of ground improvement can be determined from the relation between poisons ratio and maximum shear modulus $G_{\max }$. The latter can be estimated from the input data of shear wave velocity $v_{S}$ according to the following equation:

$G_{\text {max }}=\rho v_{s}^{2} \quad \ldots \ldots . .1$

Where $\rho$ is the bulk density of the soil $\left(\mathrm{kg} / \mathrm{m}^{3}\right)$.

\section{Vibro Stone Column}

Stone columns are progressively being employed as ground improvement elements for supporting a broad range of structures for many soil type and load situations. They construct by ramming or vibro-flotation technique depending on many factors which were summarized by [10]. Upon loading, the shear stresses generates along the side of the column wall and at the base resulting in transferring the load to the adjusted soil. So, stone columns acquire their capability from the lateral resistance of the surrounding soil [17]. This mechanism of stresses transferring causes in producing many loading mode of failure which affect significantly the enhancement achieved by this technique. So, it is crucial to investigate the degree of improvement achieved upon the reinforcement with the stone column to have a good understanding of the composite system of the soil and the inserted column. Many investigations had been conducted to study the general behaviour of stone column and the associated impact on the ground. However, the traditional field method was very costly and time consuming and required drilling deep bore holes. For popular laboratory studies, they were not be capable to detect the hidden layers of the stone-soil composite upon loading or socking with water. Consequently, many investigators examined the system performance through geophysical testing such as electrical resistivity [10] and shear wave velocity [3-9]. Examples on using the seismic waves in 


\section{University of Thi-Qar Journal Vol.14 No. r June 2019}

Web Site: https://jutq.utq.edu.iq/index.php/main

\section{Email: journal@jutq.utq.edu.iq}

investigation of the ground improvement with vibro stone column will be reviewed and discussed in the following section.

On other hand, vibro stone columns are frequently utilized in geotechnical earthquake engineering to mitigate the liquefaction potential of the soil which characterized with loose granular particles such as sand and silt and under such circumstances the shear wave test will be more proper due its vibration nature that can simulate the seismic action [18].

\section{Examples of the Applications of Elastic Seismic Waves in Ground Improvement with Vibro Stone Columns}

Early presenting to the measurement of surface shear wave velocity has been introduced by the Building Research Establishment (BRE) to determine the settlement and compare the results with those of conventional loading tests before and after reinforcement with stone column. The method showed limitations concerning short-term performance [2]. Also, pre- improvement and post-improvement measurements via shear wave was conducted by Redgers et al. [3] to detect the stone column stiffness and they were compared to the field findings of standard penetration test SPT and cone penetration test CPT. The data gained from the shear wave survey showed that the modulus of elasticity of the composite cell of the granular column and the surrounding soil increased noticeably with respect to time due to drainage impact and decreasing the pore water pressure. In addition, this geophysical method gave more consistency over a wide region in comparison to the conventional site tests. Also, a spectral shear wave distribution had been analysed by [6] to estimate the lateral characteristics of the soil before and after the remedy via vibro stone column. The seismic experiments gave a good quality data with in an acceptable resolution. A 2D compression P-wave refraction tomography method was visualized to assess the variation in the soil profile upon reinforcement with vibro replacement by [4]. The tomography of the acquisitioned data showed a clear difference in the soil profiling prior and after the treatment by inserting an array of columns as shown in Figure 4. 
University of Thi-Qar Journal Vol.14 No. r June 2019

Web Site: https://jutq.utq.edu.iq/index.php/main

Email: journal@jutq.utq.edu.iq
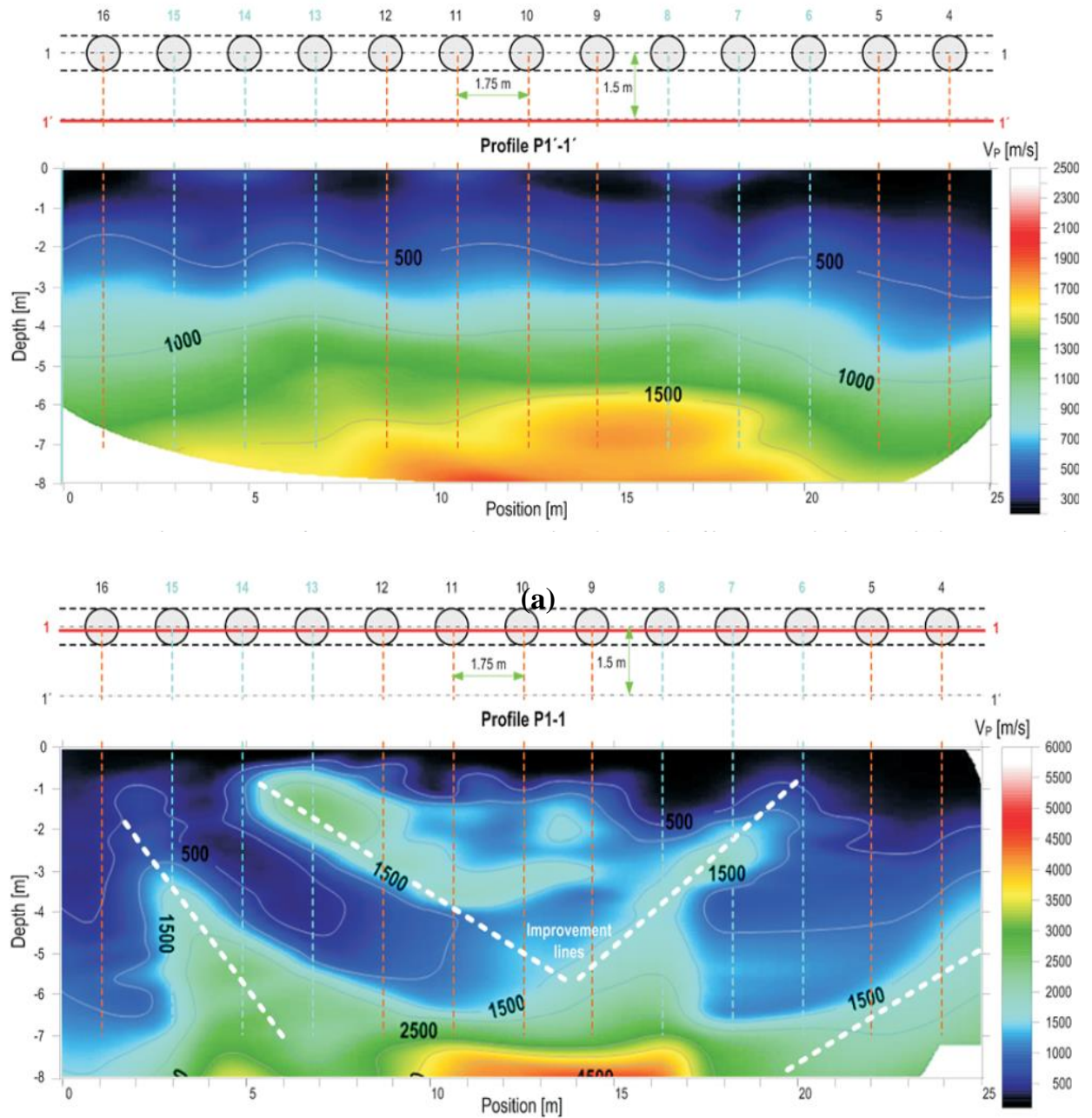

(b)

Figure 4: The seismic wave tomography of the soil profile (a) before treatment (b) after treatment [4]

Although the high resolution of the image was gained, the accuracy of the results could be considered as unreliable due to the presence of the water which could affect significantly the measurements and they may need to be reevaluated or compensated in some matter. Madun [5] developed a seismic surface wave system in the laboratory (Figure 5) for using measurements in interpretation vertical and lateral shear modulus, and therefore be capable to assess the value of ground treatment achieved 


\section{University of Thi-Qar Journal Vol.14 No. r June 2019}

Web Site: https://jutq.utq.edu.iq/index.php/main

\section{Email: journal@jutq.utq.edu.iq}

when using vibro stone columns. The author established an optimal surface wave testing array as a data acquisition system to examine both the longitudinal and vertical profiles of the phase velocity. The key focus was investigating the horizontal heterogeneity due to column installation with respect to the surface wave outcomes. The investigator used the maximum and minimum frequencies that are beneficial in spectral analysis and transmission to maximize the signal-to-noise ratio. Limitation of the method was discussed, it was noticed that the longest distance of a sensor from the seismic source demonstrated the most severe misrepresentation and result in the deficiency of signal consistency.

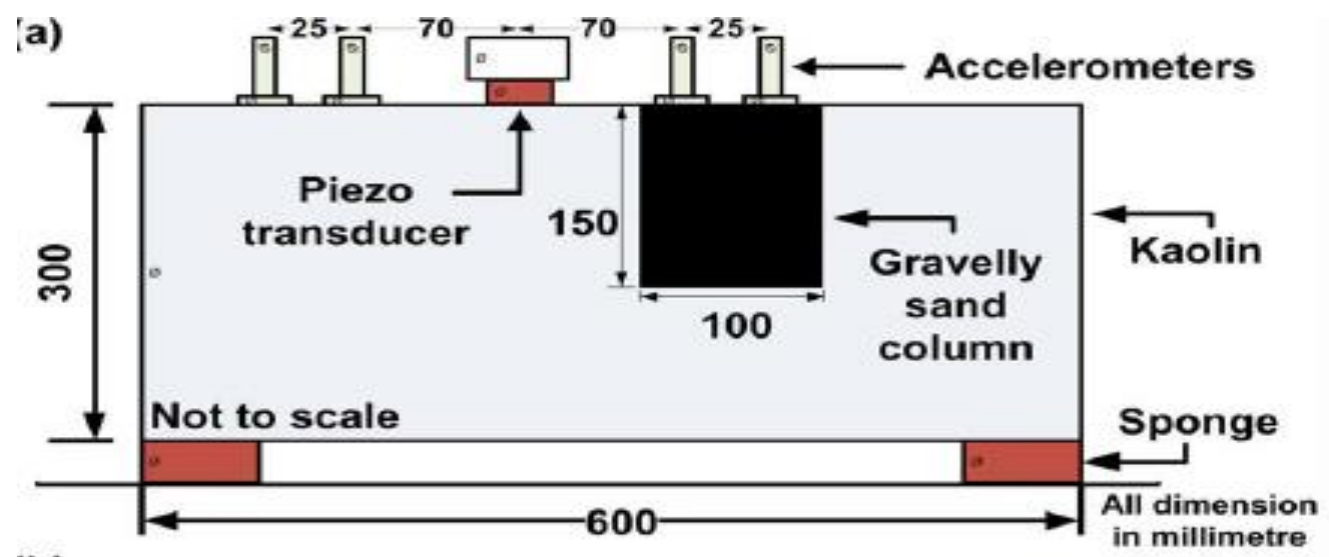

(b)

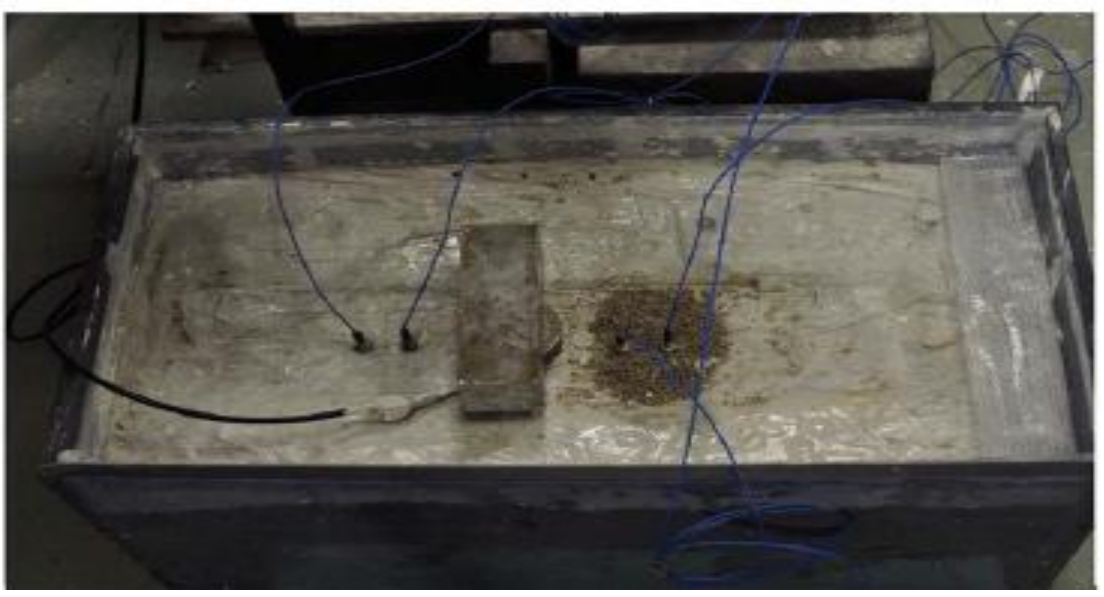

Figure 5: The setup of the laboratory physical model [5] 


\section{University of Thi-Qar Journal Vol.14 No. r June 2019}

Web Site: https://jutq.utq.edu.iq/index.php/main

\section{Email: journal@jutq.utq.edu.iq}

The receiver sensor of $10 \mathrm{kHz}$ could not achieve the higher frequency behaviour for the granular material which estimated up to $60 \mathrm{kHz}$. The wavelength was insufficient to coat the entire physical model depth. Furthermore, there was inadequate sensor energy to remain along its straight pathway when a seismic wave transmits near the body of granular column, as a part of the energy was suffered from reflection or refraction. Stuedlein et al.,[7] described a case history study where vibro granular column was employed to reduce the potential for liquefaction, cyclic softening, and volumetric strain. Shear wave velocity test incorporated along with standard penetration test and cone penetration test. Findings illustrated that stiffening of the site increases with increasing the replacement ratio ar which represents the area of stone column to that of the composite zone of the column and the influenced soil see, Figure 6. It is worth mentioned here that a disorder and decline in shear velocity was noticed near the ground surface due to the absence of confinement, amplification occurring from the vibro-probe, and the short period between installation and performing the test. 
University of Thi-Qar Journal Vol.14 No. Y June 2019

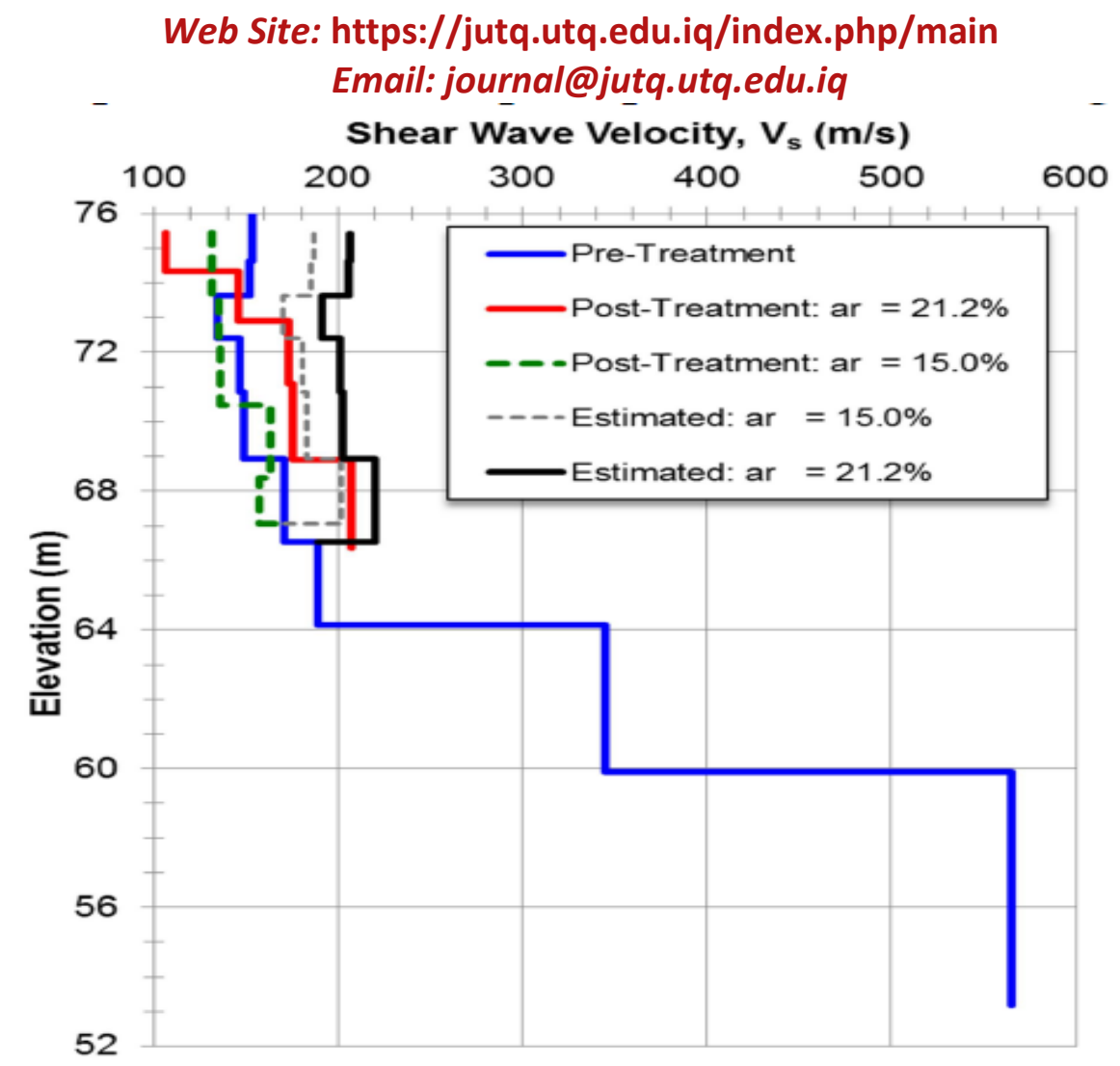

Figure 6: The shear wave velocity pre and post treatment for different area replacement ratio of stone column [18]

Motalebian et al., [19] produced a numerical study and defined the term "amplification factor" of the site that can be defined as shear wave velocity of stone column to that of soil. The model stone column was simulated in three dimensions (3D) using the software of ABAQUS, see Fig.7. The aim was to evaluate the effects of different factors on the achieved degree of improvement including depth of soil layers, shear wave velocity of soil, shear wave velocity of column, spacing among columns, diameter of stone column, length of stone column, and configuration of stone columns (square or triangle pattern). Outcomes indicated that the presence of stone columns can raise the major frequency of the location up to three times. In addition the effects of the 


\section{University of Thi-Qar Journal Vol.14 No. r June 2019}

Web Site: https://jutq.utq.edu.iq/index.php/main

\section{Email: journal@jutq.utq.edu.iq}

floating stone columns was substantially insignificant in comparison to end bearing stone column due to the absence of the column base.

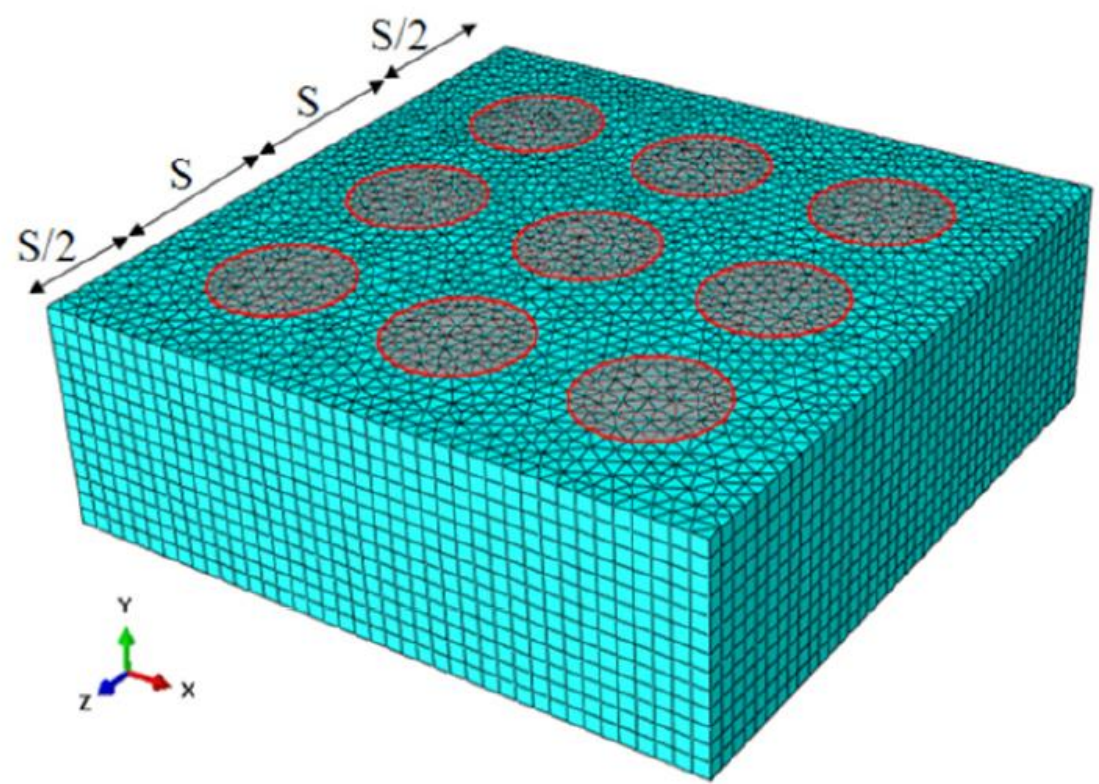

Figure 7: The stone column model in ABAQUS [19]

Toha [8] conducted a seismic down hole and multi shear wave measurements at a potentially liquefiable site, where concrete piles and granular column were provided to treat the foundation soil and minimise the seismic hazard. The selected site is part of a refinery located in high seismicity zone. The seismic measurements were done prior and after the piles and columns installation. The intense of column densification, strengthening, and pore water dissipation was elaborated. The quantity results as described by the author were fundamentally reliable and fit with the most recent theoretical expansions and showed that the support and reinforcement due to liquefaction mitigation is greater than expected.

Yanguo et al. [20] assessed a preliminary design procedure of stone column upon potential earthquakes through a field study of a thermal power plant in Indonesia. The efficiency of improved ground was assessed by shear wave velocity and standard penetration measurements The achieved improvement was acceptable and resultant in no 


\section{University of Thi-Qar Journal Vol.14 No. r June 2019}

Web Site: https://jutq.utq.edu.iq/index.php/main

\section{Email: journal@jutq.utq.edu.iq}

liquefaction during successive strong earthquakes. Authors proposed a method of correlations of liquefaction resistance, shear wave velocity, and void ratio of sandy soils, based on this method, the requisite level of ground improvement will come across whenever the target shear velocity of soil was high enough such that it does not go below the critical velocity to resist the specified earthquake intensity according to the liquefaction resistance and shear wave velocity relationship, and afterward this condition is moved to the governor of target void ratio according to the shear wave velocity and void ratio relationship.

\section{Conclusions}

The seismic shear wave tests are relatively quick, simple, non-destructive, and inexpensive. They can cover large volume of an investigated area in comparison to popular investigations such as standard and cone penetration tests. The latter are mainly borehole examinations which need drilling equipment, time, and cost. Recent publication presented the seismic shear wave tests for monitoring the performance of vibro granular column and specifically for duplicating the impact earthquake on the seismic ground. Although there were many advantages over using such geophysical tests but there were many limitation and disadvantages were mentioned in the literature. Thus, this method is still conducted in combination with borehole works because the obtained integrated image that can provide vertical and horizontal profiles and consequently contribute of the performance interpretations. To consider such method as a standard and reliable tool in detecting vibro stone column, more studies are required.

\section{References}

1. Sivakumar, V, Mckelvey, D, Graham, J., \& Hughes, D. Triaxial tests on model sand columns in clay. Canadian Geotechnical Journal. 2004, 41(1): p. 299-312.

2. Esrig, M. I., \& Bachus, R. C. Deep foundation improvements: design, construction and testing. ASTM Special Technical Publication. Philadephia: American Society for Testing \& Materials.1991. 


\section{University of Thi-Qar Journal Vol.14 No. r June 2019}

Web Site: https://jutq.utq.edu.iq/index.php/main

Email: journal@jutq.utq.edu.iq

3. Redgers, J. D., Moxhay, A. L., Ghataora, G. S., \& Jefferson, I. Case histories of settlement performance comparisons on ground improvement using soil stiffness seismic wave and traditional methods. In Sixth International Conference on Case Histories in Geotechnical Engineering. 2008: p. 1-8.

4. Gazdek, M., Strelec, S., \& Rezo, M. Estimation of vibro replacement by compression seismic waves. Tehnicki Vjesnik. 2011, 18(2): p. 243252.

5. Madun, A. Seismic evaluation of vibrostone column. PhD thesis, School of Civil Engineering, University of Birmingham. 2012.

6. Madun, A., Jefferson, I., Foo, K. Y., Chapman, D. N., Culshaw, M. G., \& Atkins, P. R. Characterization and quality control of stone columns using surface wave testing. Canadian Geotechnical Journal 2012, 49(12): p.1357-1368.

7. Stuedlein, Armin W. 1, Abdollahi, Abbas, Mason, H. Benjamin, \& French, Rowland. Shear wave velocity measurements of stone column improved ground and effect on site response. Geotechnical Special Publication IFCEE 2015 (C) ASCE. 2015: p. 2306-2317.

8. Toha, Franciscus Xaverius. Increase of in-situ measured shear wave velocity in sands with displacement pile and stone column inclusions. Jurnal Teknik Sipil, 2017, 24(1): p.1-10.

9. Butcher, A.P. \& Powell J.J.M. Practical considerations for field geophysical techniques used to assess ground stiffness." In Craig, C. (ed) Advances in site investigation practice. London: Thomas Telford. 1995: p. 701-714.

10. Al-Obaidy, Nesreen. Treatment of collapsible soil using encased stone columns. Ph.D. thesis, University of Birmingham, Birmingham , UK. 2017

11. Peter M. Shearer. Introduction to seismology. Book, 2nd edition. Publisher is Cambridge University Press. 2009.

12. Al-Hunaidi M.O. Insight on the SASW non-destructive testing method. Canadian Geotechnical Journal. 1993, 20: p. 940-950. 


\section{University of Thi-Qar Journal Vol.14 No. r June 2019}

Web Site: https://jutq.utq.edu.iq/index.php/main

\section{Email: journal@jutq.utq.edu.iq}

13. Bruce A. Bolt. Retrieved from

https://www.britannica.com/science/earthquake-geology/Shallowintermediate-and-deep-foci, 2018.

14. Liao, T., \& Mayne, P. WStratigraphic delineation by threedimensional clustering of piezocone data Georisk: Assessment and Management of Risk for Engineered Systems and Geohazards. 2007, 1(2): p. $102-119$.

15. Menzies, B. \& Matthews, M. The continuous surface-wave system: A modern technique for site investigation. In Special lecture: Indian Geotechnical Conference Madras. December 11-14th 1996.

16. Clayton, C.R.I., Gordon, M.A., \& Matthews, M.C. Measurements of stiffness of soils and weak rocks using small strain laboratory testing and geophysics. In: Craig, C. (ed.) Proceedings of an International Symposium on Pre-failure Deformation 17, Characteristics of Geomaterials. Rotterdam, Balkema. 1994: p. 229-234.

17. Hughes, J. M. O., \& Withers, N. J. Reinforcing of soft cohesive soils with stone columns. Ground Engineering 1974, 1(3): p. 42-49.

18. Murali KM, and Madhav MR. Engineering of ground for liquefaction mitigation using granular columnar Inclusions: Recent developments. American Journal of Engineering and Applied Sciences. 2009; 2(3): p.526-36.

19. Masoud Motalebian, Masoud Hajialiliue Bonab \& Mohamma Davoudi Numerical estimation of the fundamental frequency of improved sites with stone columns. Indian Journal of Science and Technology, 2015, 8(19): p. 1-6.

20. Yanguo Zhou, Zhengbo Sun, Jie Chen, Yunmin Chen, \& Renpeng Chen. Shear wave velocity-based evaluation and design of stone column improved ground for liquefaction itigation. Earthquake Engineering and Engineering Vibration. 2017, 6(2): p. 247-261. 